\title{
舞鶴発電所新設工事における 大規模揚炭栈橋の施工 CONSTRUCTION OF THE LARGE-SCALE JETTY AT MAIZURU THERMAL POWER PLANT
}

\author{
寺田昌史 ${ }^{1} \cdot$ 中村敏昭 ${ }^{2} \cdot$ 大政康司 $^{3} \cdot$ 大村啓一 $^{4} \cdot$ 秋里乃武宏 $^{5}$ \\ Masashi TERADA,Toshiaki NAKAMURA,Yasushi OOMASA,Keiichi OOMURA \\ and Nobuhiro AKISATO
}

\author{
${ }^{1}$ 正会員 工修 関西電力株式会社 土木建築室（广530-8270 大阪府大阪市北区中之島 3-3-22） \\ 2, 3 関西電力株式会社 舞鶴火力建設所土木工事課（广６25-0135 京都府舞鶴市字千歳 500 番地） \\ ${ }^{4}$ 正会員 工修 大成建設株式会社 関西支店営業部（テ542-0081 大阪府大阪市中央区南船場 1-14-10) \\ ${ }^{5}$ 正会員 大成建設株式会社 土木本部 土木設計第 2 部（广163-0606 東京都新宿区西新宿 1-25-1）
}

The large-scale jetty was constructed as one of the facilities for a new thermal power plant (generating power : 1,800,000 kw ) in Maizuru City, a project of the Kansai Electric Power Co., Inc. In the construction of the jetty, the new quality control method was applied in pilings and the new-type hammer was developed in order to remove stones that made pile-driving difficult. Also, the new method was applied for construction of the superstructure.

This paper presents the new quality cont rol method for pilings and the new construction methods that were applied and developed for large-scale jetty construction.

Key Words : pilings, statnamic loading test, dynamic loading test, submergible mobile stage

\section{1. 概 要}

関西電力（株）は, 現在, 京都府舞鶴市に出力 180 万 kW (90万 $\mathrm{kW} \times 2$ ) の石炭火力発電所を 建設中である. 発電所施設のうち，揚炭栈橋は国内 最大級の規模であるばかりでなく，地層構成が複雑 であることや上部工から海面までのクリアランスが 少ないなど，その施工に際しては解決すべき様々な 技術的課題があった。

ここでは， 2 種類の載荷試験を活用した杭の支持 力管理, 杭打ちの障害となる転石除去のために開発 したオフショア式重錘中掘ハンマ, そして上部工施 工に採用した潜水式可動型枠支保工（TSM-W）に ついて報告する.

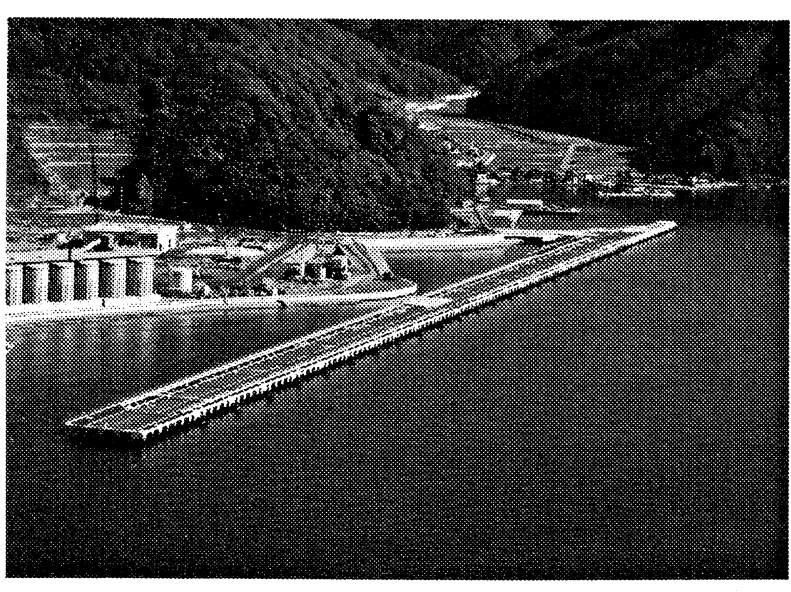

写真-1 揚炭栈橋全景 


\section{2. 工事の内容}
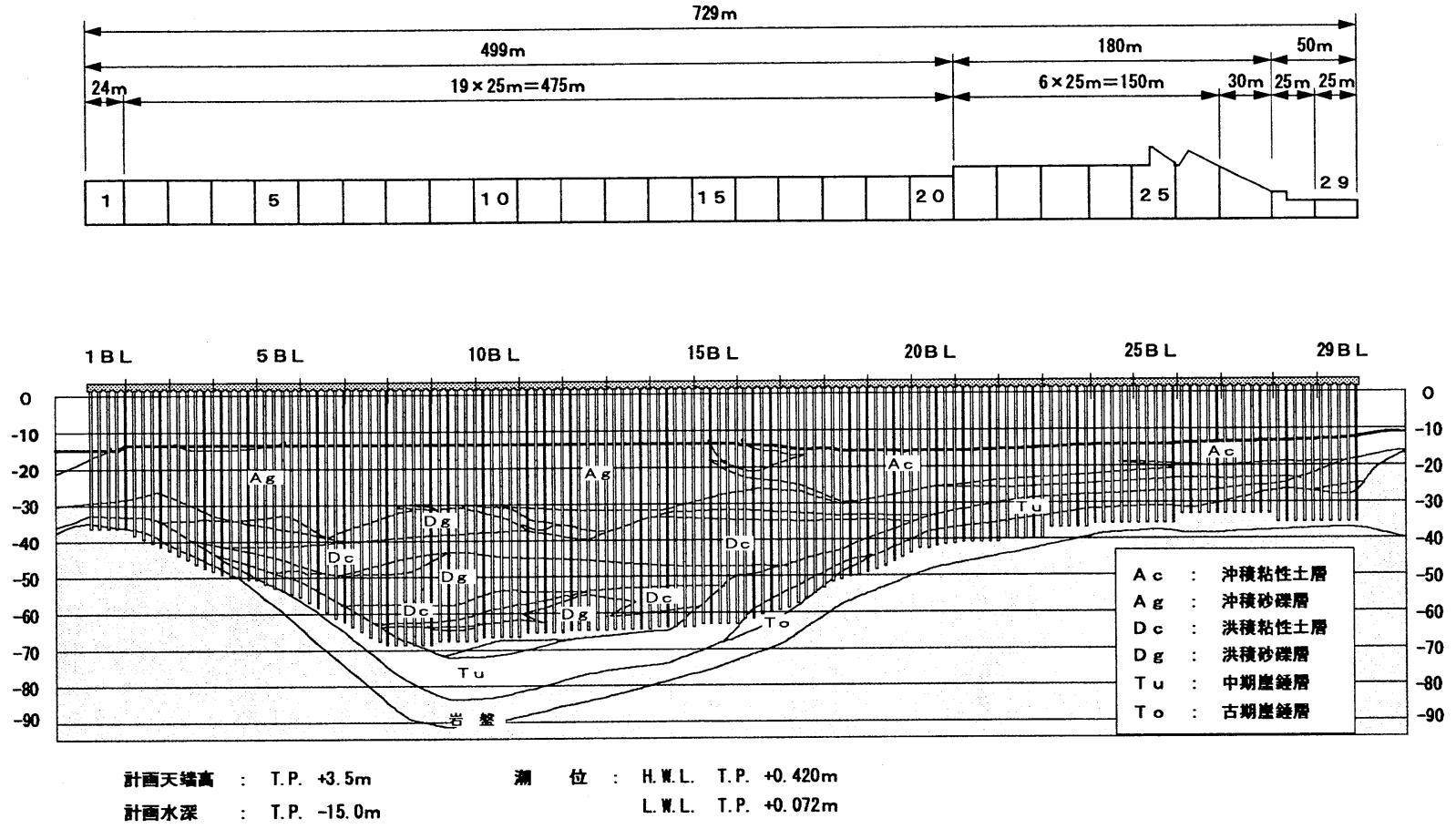

図-1 揚炭栈橋平面図および地層断面図

\section{(1) 施設の概要}

発電所建設地点は若狭湾国定公園内に位置する: とから, 風光明媚な海岸線を保全するために，揚炭 栈橋は沖出方式となっており，70,000DWT 級の石 炭運搬船が着栈可能な揚炭バースが 2 バースと 3,000DWT 級の船舶が着栈可能なユーティリティバ 一ス 1 バースの計 3 バースから構成される. 揚炭栈橋の概要は以下に示寸通りである.

構造形式: 直杭式横栈橋（29ブロック）

上部工 鉄筋コンクリート造

下部工 鋼管杭 $(\phi 1,200 \sim \phi 1,700)$, 杭本数 735 本

栈橋諸元：延長 $729 \mathrm{~m}$, 幅 $10 \sim 30 \mathrm{~m}$

\section{(2) 地盤条件}

栈橋建設地点は, 輝緑凝灰岩または粘板岩の上に 崖錘と堆積層が覆った地層である．図-1 からもわ かるように, 栈橋法線平行方向の地層構成は非常に 複雑で，支持層の梁度も大きく変化している．この ため, 端部ブロックの基礎杭は岩盤を支持層とし， 中央付近では洪積砂砂層（Dg）を支持層として打 ち止める設計となっている. また，栈橋法線直角方 向への地層変化も大きく，栈橋 1 ブロックの中にお いてさえ，打ち止め位置が $10 \mathrm{~m} \sim 15 \mathrm{~m}$ も異なる.

地質調查結果によれば，沖積砂砂層 $(\mathrm{Ag})$ と洪 積砂砂層 $(\mathrm{Dg})$ には直径 $50 \mathrm{~mm} \sim 900 \mathrm{~mm}$ 程度の転 石が出現しており，鋼管杭打設の障害となることが

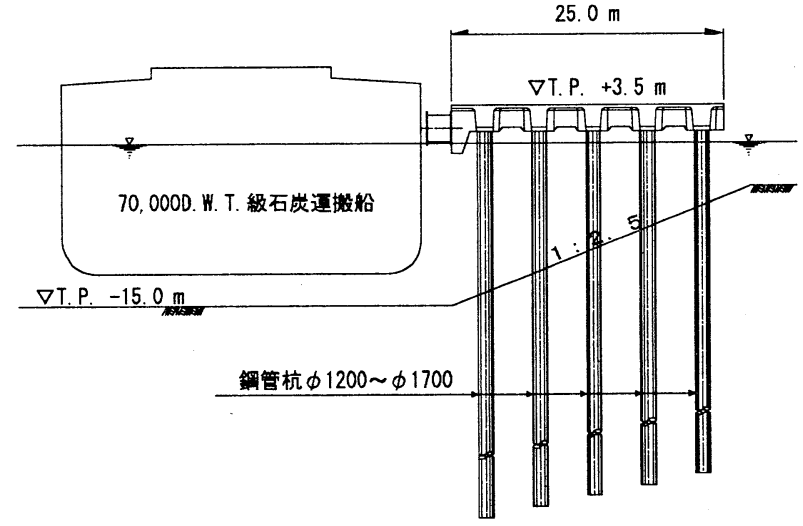

図-2 揚炭栈橋標準断面図

予測されていた。

\section{3. 施エ上の課題と対策}

\section{1 杭の支持力管理}

\section{(1) 採用の背景}

鋼管杭の支持力は, 打止め時の貫入量とリバウン ド量を測定して Hiley に代表される動的支持力公式 によって推測するのが一般的な手法である.しかし， 本栈橋の基礎杭は大口径長尺杭であること, 地層構 成が複雑で杭支持地盤の種類および支持層レベルが 
場所によって大きく変化していることから，打設に 際して精度の良い支持力管理手法が必要とされた。 このため，急速載荷試験（STATNAMIC 試験）と衝 撃載荷試験，および波動理論に基づく杭打ち解析を 活用した支持力管理を実施した.

\section{（2）杭の打設方法}

栈橋基礎杭は，1,600t 吊り全旋回式起重機船と自 己昇降式作業台船（SEP），および杭打ち用のリ一 ダ一を装備した $1,700 \mathrm{t}$ 吊り全旋回式起重機船を使 用して，以下の手順で打設した。

a）SEP またはリーダーに取り付けたキーパー をガイドとして杭を建て込み，杭が自立するま

で偏心モーメント $3.92 \mathrm{kN} \cdot \mathrm{m}$ のバイブロハン マにて打設する.

b）次に $490 \mathrm{kN} \cdot \mathrm{m}$ の打撃エネルギーを有する 油圧ハンマに取り替えて, 所定の支持力が得ら れる深度まで打ち下げる。

杭の打設状況を写真-2 に示す.

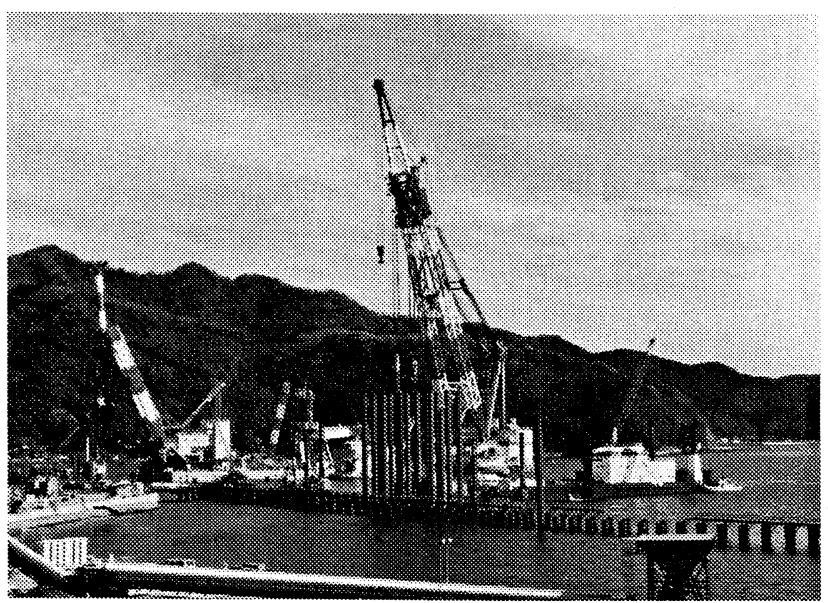

写真-2 大型起重機船による杭打設状況

\section{(3) 支持力の管理手法}

図-3 は，杭の支持力管理の基本フローと，今回 実施した各種載荷試験の位置付けを示したものであ る. 図中にも示すように，事前に試験杭（8 本）を 打設し，衝撃載荷試験を行うことによって，地盤の パラメータと打設時の支持力（動的貫入抵抗力）を 把握した.

次に, 8 本の試験杭のうち 2 本で STATNAMIC 試 験を実施し, 杭打設後の支持力の回復率（セットア ップ率=静的極限支持力 /杭打設時動的貫入抵抗） を推定した（詳細は参考文献 1）を参照されたい).

事前解析においては, 波動解析プログラム （TNOWAVE）を用いて栈橋の各施エブロックごと に杭の 1 打撃当りの貫入量と支持力の相関図（管理 図）を作成し，打設時の打止め管理に活用した。こ れは，波形マッチングによって得られたパラメータ をもとに，当該杭の打設時動的貫入抵抗を推定し， 前述のセットアップ率を乗じて最終（静的）支持力

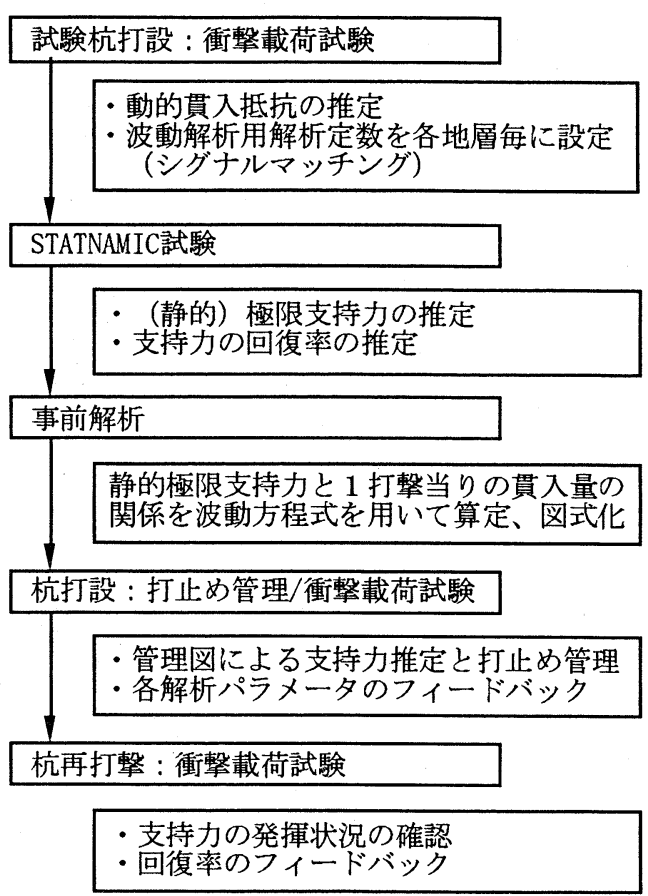

図-3 杭打設時における支持力管理のフロー

を推定するものである.

本設杭の打設において，支持力管理のために実施 する作業はハンマの打撃エネルギーの管理と杭の貫 入量の計測だけである。しかも貫入量の計測は対岸 からの測量で行う（貫入量 $10 \mathrm{~cm}$ 当りの打撃回数よ り逆算する）ため，精度の良い支持力の管理が安全 にかつ効率的に実施できた。

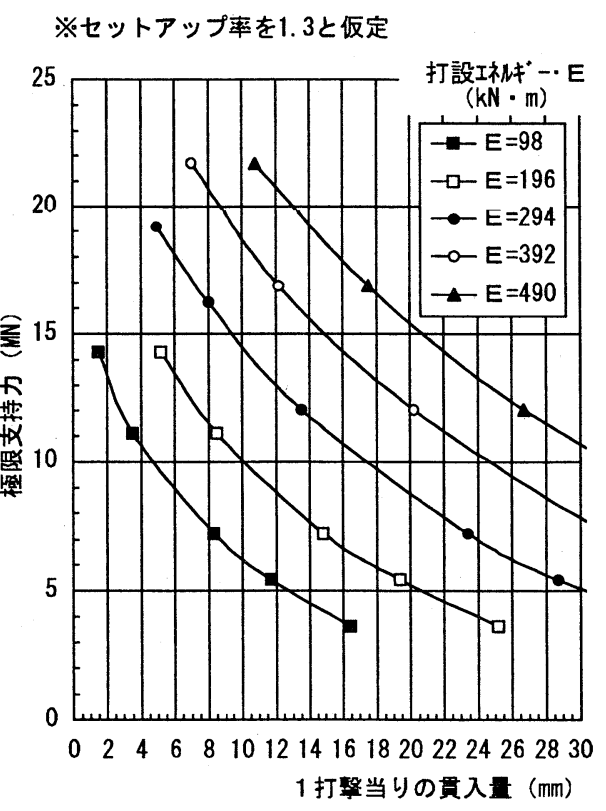

図-4 支持力管理図（例）

また，衝撃載荷試験を各ブロック 2 本以上実施し て，回復率や各地盤のパラメータのフィードバック を行った. 
(4) 実施結果

a) 試験工事によって定めた回復率 1.3 に対して, 見直しが必要となったのは, 砂礫層が多い4つ のブロックの杭であったが，その值は $1.2 \sim 1.6$ であった.

b） N 值が 50 を越える洪積砂䃇層は支持層とし て期待されたが，衝撃載荷試験から得られた杭 との周面摩擦力や先端支持力は小さく, 支持層 とはなりえなかった。

c) 衝撃載荷試験の計測時に得られる全抵抗値 と打設時の貫入抵抗力には, 杭長と地盤に関係 なく図-5 に示す相関があった。これにより， 適当な回復率を設定すれば，全抵抗の計測のみ で杭の支持力を推測することが可能となる.

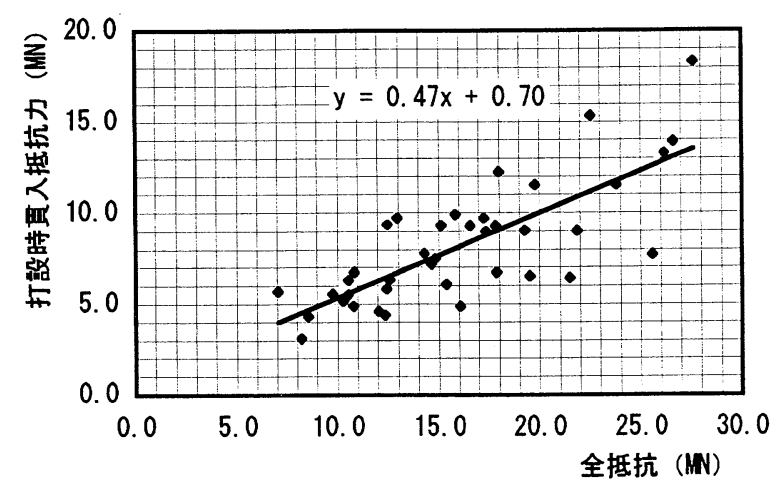

図-5 全抵抗と打設時貫入抵抗力の相関

\section{2 オフショア式重錘中掘ハンマ}

\section{(1) 開発の背景}

中間の砂碟層に杭の打設が困難となる転石が出現 することは，地盤条件で述べたとおりである．当初 の検討段階で考えた障害対策工法は，掘削はハンマ 一グラブにより行い，障害となる転石を砕くために 重鍾を利用するものであった。しかし，この方法で は，ハンマーグラブの施工上の制約（海面からの杭 の突出長が $20 \mathrm{~m}$ 以上の場合と大染度においては掘削 作業が困難）から，鋼管杭を切断しなければ障害対 策が実施できないという問題点があった。しかも、 障害が発生するたびに杭の切断〜障害除去〜杭の溶 接という作業を繰り返していては，杭の品質が低下 するとともに工程管理が困難という問題もあった.

一方，本工事で採用したオフショア式重錘中掘八 ンマの原型ともいうべき重鍾掘削工法は, 岩盤掘削 に効果を発揮して実積をあげていることが調查の結 果わかっていた．そこで，機械を支持するための夕 ワーや重機，そしてそれらを載荷するためのステー ジが必要, 発生深度が特定できないため掘削土の処 理システムに見直しが必要, という問題点を解決の 上，本工事で採用することとした。

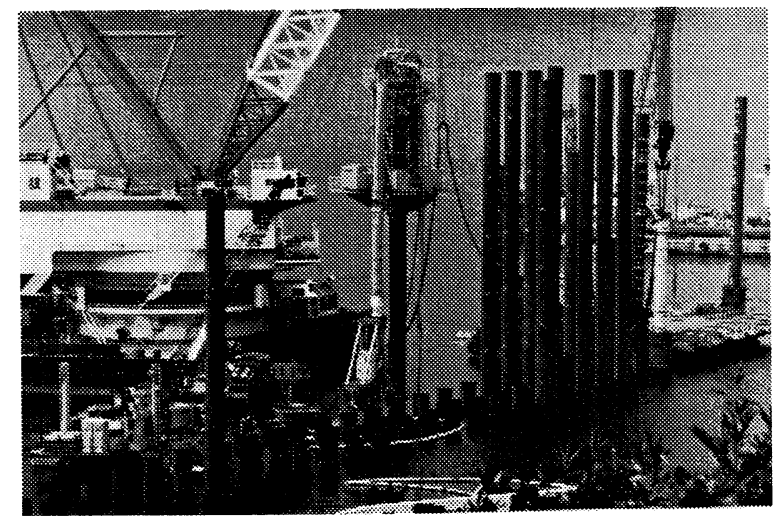

写真-3 オフショア式重錘中掘ハンマによる施工状況

\section{(2) オフショア式重鍾中掘ハンマの概要}

オフショア式重錘中掘ハンマには，以下のような 特徴がある.なお, メカニズムの詳細については, 参考文献 2)を参照されたい.

a) パワープラント, ウィンチ, 油圧ハンマ等 のほとんどのシステムがパッケージ化された.

このため, 1 台で掘削〜掘削士処理〜杭打設の 一連の作業が可能である.

b）杭が自立すれば杭頭に搭載するだけで安定 するため, 起重機船で常時吊っておく必要はな く, 障害対策と杭打ちが並行して実施できる.

c）掘削土の排出管は伸縮式であるため, あら ゆる梁度に対応が可能である.

d）低騒音・低振動であるため, 周辺に与える 影響が小さい.

e）ずり処理に使用される水は循環利用される ため, 海域污染の心配がない.

機械仕様を表-1に示す.

\begin{tabular}{|c|c|c|}
\hline 設 & \multicolumn{2}{|c|}{ 様 } \\
\hline フライングリーダー & \multicolumn{2}{|l|}{$\begin{array}{l}\text { 総重量 } 120 \mathrm{tf} \\
3.5 \mathrm{~m} \times 3.8 \mathrm{~m} \times 10.2 \mathrm{~m}\end{array}$} \\
\hline 油圧ハンマー & \multicolumn{2}{|c|}{ 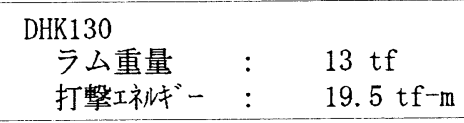 } \\
\hline パワープラント & $\begin{array}{l}\text { 油圧ハンマー駆動用 } \\
\text { 油圧ウィンチ駆動用 }\end{array}$ & $\begin{array}{l}1 \text { 基 } \\
1 \text { 基 }\end{array}$ \\
\hline 油圧ウィンチ & \multicolumn{2}{|c|}{$\begin{array}{l}\text { 重鍾用 } 1 \text { 基 }(66 \mathrm{~m} / \mathrm{min}) \\
\text { ずり管用 } 1 \text { 基 }(22 \mathrm{~m} / \mathrm{min})\end{array}$} \\
\hline ずり揚管 & \multicolumn{2}{|c|}{$\begin{array}{l}\text { 伸縮式および固定式 } \\
\text { 内径 } 225 \mathrm{~mm}\end{array}$} \\
\hline 錘 & $\phi 1400$ 用 $(6.4 \mathrm{tf}), \phi 16$ & 600用 $(6.8 \mathrm{tf}$ \\
\hline
\end{tabular}

表-1 オフショア式重錘中掘ハンマの仕様

(3) 実施結果

a) 揚炭栈橋鋼管杭 735 本のうち, 転石除去の 障害対策を実施した杭は 175 本であり，このう ちオフショア式重鍾中掘ハンマを必要とした杭 は 20 本であった。 
b）地盤に忘じて重錘の落下高を変化させたが， 粘性土層では $0.5 \mathrm{~m}$, 砂砂層では $1.5 \mathrm{~m}$ が効率的 であった。

c）中間地盤の掘削速度は時間当り $1 \mathrm{~m} \sim 2 \mathrm{~m}$ 程度 であったが，一般的に砂質地盤が早く粘性土層 が遅いという傾向があった.

d）先端の障害除去については，先端にある転 石の状況によって異なるが， 1 時間〜2 時間程 度で破砕除去できた。

e）杭先端の障害除去には有効なハンマである が, 総重量が $120 \mathrm{t}$ もあり大型起重機船が必要 となるため, 汎用的に活用するためには更に軽 量化する必要がある.

\section{2 潜水式可動型枠支保工（TSM-W）}

\section{(1) 開発の背景}

栈橋上部工の型枠支保工は, 図-6に示すように, 杭にブラケットを取り付けてその上に $\mathrm{H}$ 型鋼を受け 桁として配置し，型枠支保工を組み立てるのが一般 的である。しかしながら，本栈橋は海面までのクリ アランスが約 $0.5 \mathrm{~m}$ しかないため, ほとんどが水中 作業になるという問題点があった。すなわち，施工 時の作業員の安全性の確保, 施工時波浪に対して十 分な耐力を有するという構造的な安全性の確保, と いう 2 つの問題をクリアする必要があった。また, 本栈橋は総延長が非常に長いということから，鋼製 の型枠支保工を製作してもコスト増にならないため, 本工法を採用することとした。

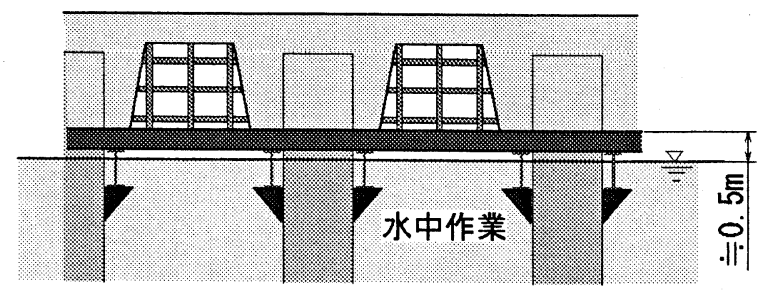

図-6 現場組み支保工概念図

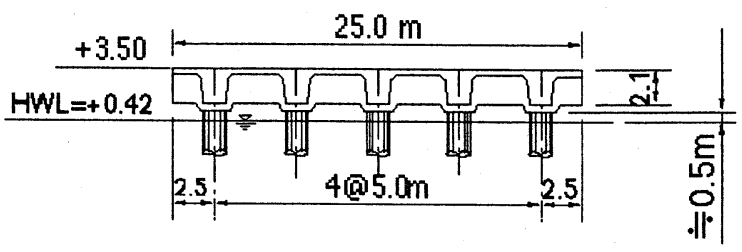

図-7 上部工標準断面図

(2) 設計上の配慮

本工法を採用するにあたり，以下の配慮をした。

a) 杭を延長方向に等ピッチとした.

b）梁断面は，型枠の脱型がしやすいように， 下側にむけてテーパーをもたせた台形とした。 c）アンローダーレール直下以外の桁断面は, できる限り同じとした，さらに，杭の埋込み長 不足に対しては杭頭に支圧板を取り付け，断面 力の相違に対しては鉄筋量の増減によって対処 した.

\section{(3) TSM-W 型枠支保工の概要}

TSM-W は杭間 1 列分の型枠と支保工が一体化さ れたものであり, イカダのように海面に浮かせて移 動し，杭から吊り下げた PC 鋼棒によって固定した 後, 隣接ブロックと連結することによって設置する ものである.

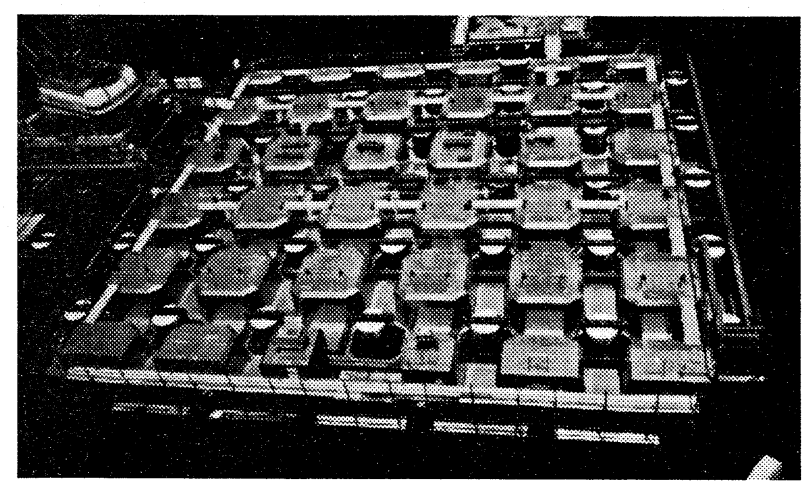

写真-4 TSM-W セット完了後全景

TSM-W は以下の特徽を有している.

a) 上部エ 1 ブロック分を 5 つのユニットに分 割した工場製作品であるため，均一断面とする ことができる.

b）支保工と型枠が一体化しており，梁とスラ ブが一括打設できる耐力を有している.

c）長期間使用するため, 型枠表面は SUS 材を 使用している.

d）梁の底枠とスラブの側枠は、ヒンジ回転と スライド移動により、格納・伸縮が可能となっ ている.

e）吊り上げはクローラクレーンで行い，脱型 後の吊りおろしは油圧ジャッキで行う。

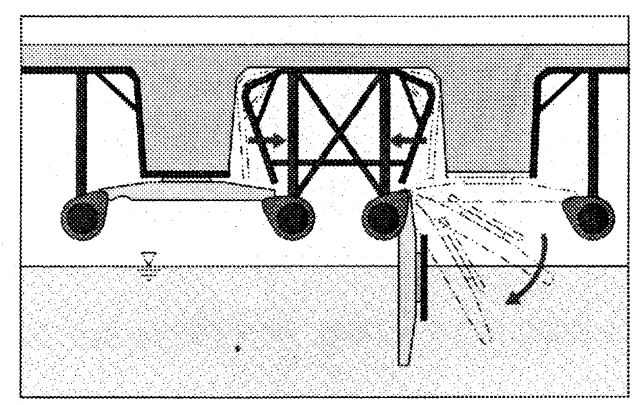

図-8 接合のメカニズム

本工事においては，上部工 2 ブロック分を 1 セッ トとして，3セット製作した. 


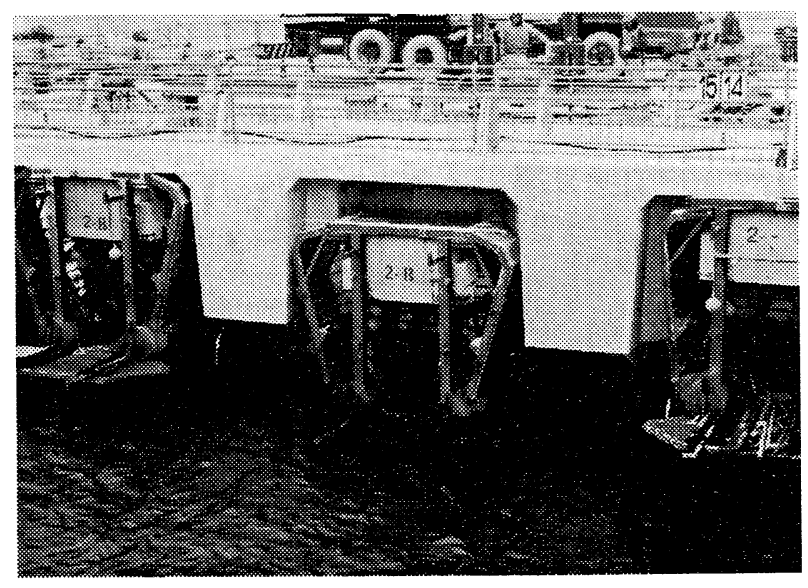

写真-5 TSM-W 脱型状況

\section{(4) 実施結果}

TSM-W の使用によって, 以下の効果があった.

a) 潜水作業や支保工材下部での作業がないこ とから, 安全性が向上した.

b）台風や荒天によって, 直接型枠支保工が波 にたたかれる事はあったが，損傷することなく 使用できた。

c）セパレータを使用せず，また梁とスラブの コンクリートを一括打設したことによって, 耐 久性の高い高品質な上部工が構築できた.

d）施工ブロックの工程は，3 月から 2 ケ月 に短縮することができた.

一方で，更に汎用的に使用するためには，以下の 課題が残された.

a）防錆のために使用している SUS 材が材料費 の高騰要因であるため, より安価な代替材料の 検討.

b）ハンチを無くすなどの躯体形状の統一.

\section{4. まとめ}

載荷試験を活用して杭の支持力管理を実施した事 例はあるが，本工事で実施したような貫入量とリバ ウンド量を計測することなく, 品質管理を実施した 例は稀である. 本工事では, 精度よく安全に管理で きる手法としてその有用性が確認された. 杭の打設 本数が少なく経済的な理由で載荷試験を実施できな い場合も多いであろうが，更なるデータの蓄積によ って, 安価で精度良く, かつ安全に評価できる手法 として発展することが望まれる.

オフショア式重錘中掘ハンマと TSM-W 工法につ いては，施工条件の悪い中でも効率性・安全性とも に優れていることが害証された.

本工事は，その規模だけでなく、地盤条件におい ても特殊な事例であった。しかし，ここで用いた管 理手法や施工法は汎用的に活用できる技術であり， 今後の研究や工事の一助となれば幸いである.

\section{参考文献}

1) 寺田昌史, 中塚龍一,大村啓一,秋里乃武宏,堀越研一, 西村 真二 : 大規模栈橋工事における杭の急速載荷試験の利 用, 第 33 回地盤工学研究発表会, pp129-130, 1998.

2) 寺田昌史,中塚龍一,大村啓一,秋里乃武宏 : オフショア 式重鍾中掘打込工法による鋼管杭打込み時の障害物対 策, 日本建設機械化協会関西支部・地盤工学会関西支 部・土木学会関西支部平成 10 年度施工技術報告会, pp29-38, 1999.

3) 寺田昌史,岸本敏宏, 大村啓一,秋里乃武宏, 堀越研一: 動 的載荷試験を活用した鋼管杭の支持力管理, 基礎工 7 月号, pp58-61, 1999. 